\title{
Enhancement of photosynthetic capacity in Euglena gracilis by expression of cyanobacterial fructose-1,6-/sedoheptulose-1,7-bisphosphatase leads to increases in biomass and wax ester production
}

Takahisa Ogawa ${ }^{1,2}$, Masahiro Tamoi $^{1,2^{*}}$, Ayako Kimura ${ }^{1,2}$, Ayaka Mine $^{1}$, Harumi Sakuyama $^{1,2}$, Eriko Yoshida $^{2,4}$, Takanori Maruta ${ }^{2,3}$, Kengo Suzuki ${ }^{2,4}$, Takahiro Ishikawa ${ }^{2,3}$ and Shigeru Shigeoka ${ }^{1,2}$

\begin{abstract}
Background: Microalgae have recently been attracting attention as a potential platform for the production of biofuels. Euglena gracilis, a unicellular phytoflagellate, has been proposed as an attractive feedstock to produce biodiesel because it can produce large amounts of wax esters, consisting of medium-chain fatty acids and alcohols with 14:0 carbon chains. E. gracilis cells highly accumulate a storage polysaccharide, a $\beta$-1,3-glucan known as paramylon, under aerobic conditions. When grown aerobically and then transferred into anaerobic conditions, E. gracilis cells degrade paramylon to actively synthesize and accumulate wax esters. Thus, the enhanced accumulation of paramylon through the genetic engineering of photosynthesis should increase the capacity for wax ester production.

Results: We herein generated transgenic Euglena (EpFS) cells expressing the cyanobacterial fructose-1,6-/ sedoheptulose-1,7-bisphosphatase (FBP/SBPase), which is involved in the Calvin cycle, to enhance its photosynthetic activity. FBP/SBPase was successfully expressed within Euglena chloroplasts. The cell volume of the EpFS4 cell line was significantly larger than that of wild-type cells under normal growth conditions. The photosynthetic activity of EpFS4 cells was significantly higher than that of wild type under high light and high $\mathrm{CO}_{2}$, resulting in enhanced biomass production, and the accumulation of paramylon was increased in transgenic cell lines than in wild-type cells. Furthermore, when EpFS cell lines grown under high light and high $\mathrm{CO}_{2}$ were placed on anaerobiosis, the productivity of wax esters was approximately 13- to 100-fold higher in EpFS cell lines than in wild-type cells.

Conclusion: Our results obtained here indicate that the efficiency of biomass production in $E$. gracilis can be improved by genetically modulating photosynthetic capacity, resulting in the enhanced production of wax esters. This is the first step toward the utilization of $E$. gracilis as a sustainable source for biofuel production under photoautotrophic cultivation.
\end{abstract}

Keywords: Euglena gracilis, Biofuel, Wax ester, Paramylon, Biomass, Fructose-1,6-/sedoheptulose-1,7-bisphosphatase, Photosynthesis

\footnotetext{
*Correspondence: tamoi@nara.kindai.ac.jp

'Department of Advanced Bioscience, Faculty of Agriculture, Kinki University,

3327-204 Nakamachi, Nara 631-8505, Japan

${ }^{2}$ Core Research for Evolutional Science and Technology (CREST), Japan

Science and Technology Agency (JST), Chiyoda-ku, Tokyo 102-0076, Japan

Full list of author information is available at the end of the article
} 


\section{Background}

The world is faced with an energy crisis due to the depletion of fossil fuels caused by growth of the global economy and population. Furthermore, the use of fossil fuels increases $\mathrm{CO}_{2}$ levels in the atmosphere. Therefore, feasible alternative energy sources are required as substitutes for fossil fuels. The production of biofuels from microalgae is now expected to become a practical solution for mitigating not only dependence on fossil fuels but also $\mathrm{CO}_{2}$ emissions. Microalgae are considered to be more advantageous than plants that are currently utilized as energy feedstocks due to their fast growth rates, high-lipid productivity, and cultivation on non-arable land areas, which does not compete with food production [1]. Therefore, extensive research has been conducted to identify useful microalgae all over the world and also improve biomass production through the metabolic engineering of known microalgae [2]. However, several problems such as the low productivity of microalgae and difficulties in consistently producing biomass at a large scale in highly variable outdoor culture conditions need to be overcome before microalgae can be used as an economically viable biofuel feedstock. To effectively improve microalgal biofuel production, the optimization of microalgal cultivation systems and the selection of species with many desirable biofuel traits are considered to be important. Furthermore, the development of genetic engineering for microalgae will be beneficial for enhancing biofuel productivity. Although genetic transformations of more than 30 different strains of microalgae have been reported [3], further research is still required to fully maximize microalgal biomass production for biofuels.

Euglena gracilis, a unicellular phytoflagellate, is widely distributed in freshwater and has been proposed as an attractive feedstock to produce biodiesel because it can produce wax esters with high productivity $[4,5]$. E. gracilis cells highly accumulate a storage polysaccharide, a $\beta$-1,3-glucan known as paramylon, under aerobic conditions; therefore, these cells accumulate up to $50 \%$ of paramylon per dry weight of the cells. When grown aerobically and then transferred into anaerobic conditions, E. gracilis cells degrade paramylon to actively synthesize and accumulate wax esters, consisting of medium-chain fatty acids and alcohols with 14:0 carbon chains being the main constituent (myristyl myristate). This phenomenon has been designated as wax ester fermentation due to the concomitant generation of ATP without any energy loss during the production of wax esters [4]. Myristic acid (C14:0) has more potential as a drop-in jet fuel than medium-length fatty acids such as palmitic acid (C16:0) and stearic acid (C18:0), because myristic acid is a component of kerosene used as jet fuel. In addition to the advantage of this resource as an alternative biofuel, E. gracilis is rich in nutrients such as vitamins, minerals, and wellbalanced amino acids [6]; therefore, it is used as feedstock of dietary supplements, in the manufacture of cosmetics, and for the fortification of livestock feed. Thus, E. gracilis is one of the most attractive and ideal possibilities for biodiesel and biomass production. The genetic manipulation for E. gracilis not only increases its biomass production but also enriches its utility.

The metabolic engineering of $\mathrm{CO}_{2}$ assimilation promises to create useful $E$. gracilis strains capable of producing industrially feasible biodiesel. One of the strategies used to enhance algal productivity is optimization of the photosynthetic pathway. The rate-limiting enzymes involved in the Calvin cycle, fructose-1,6-bisphosphatase and sedoheptulose-1,7-bisphosphatase (FBPase and SBPase, respectively), are potential targets for the optimization of photosynthetic reactions [7, 8]. We previously reported that transgenic tobacco and lettuce plants overexpressing the cyanobacterial fructose-1,6-/sedoheptulose1,7-bisphosphatase (FBP/SBPase) gene, which encodes a bifunctional enzyme having both FBPase and SBPase activities, in chloroplasts showed an enhanced $\mathrm{CO}_{2}$ assimilation rate and increased biomass production $[7,9,10]$. In order to achieve the objective of the present study, we first established transgenic E. gracilis cells expressing cyanobacterial FBP/SBPase and then showed that the introduction of the FBP/SBPase gene to microalgae improved biomass and wax ester production.

\section{Results}

Generation of transgenic $E$. gracilis cells expressing cyanobacterial FBP/SBPase

To generate transgenic $E$. gracilis, the cyanobacterial $F B P / S B P a s e$ gene with a tomato rubisco small subunit $(r b c S)$ transit peptide driven by the $35 \mathrm{~S}$ promoter and neomycin phosphotransferase II (NPT II) gene as an antibiotic-resistant marker with the nopaline synthase (NOS) promoter was introduced into E. gracilis wildtype cells by microprojectile bombardment (Fig. 1a). Several paromomycin-resistant colonies were obtained after antibiotic selection, and these transgenic E. gracilis cells were named EpFS cells. Genomic DNA was isolated from wild-type and randomly selected six EpFS cell lines, and the transgene was analyzed by genomic PCR with gene-specific primers for the FBP/SBPase sequence. As shown in Fig. 1b, the expected 937-bp fragment was detected in all EpFS cell lines, but not in the wild-type cells. Immunoblot analysis using an anti-FBP/ SBPase antibody showed that FBP/SBPase proteins were detected in the transgenic cell lines with the expected molecular size as mature proteins (approximately $40 \mathrm{kDa}$ ) (Fig. 1c). The EpFS4 cell line accumulated the highest levels of the FBP/SBPase protein. FBPase activities were 1.4- and 


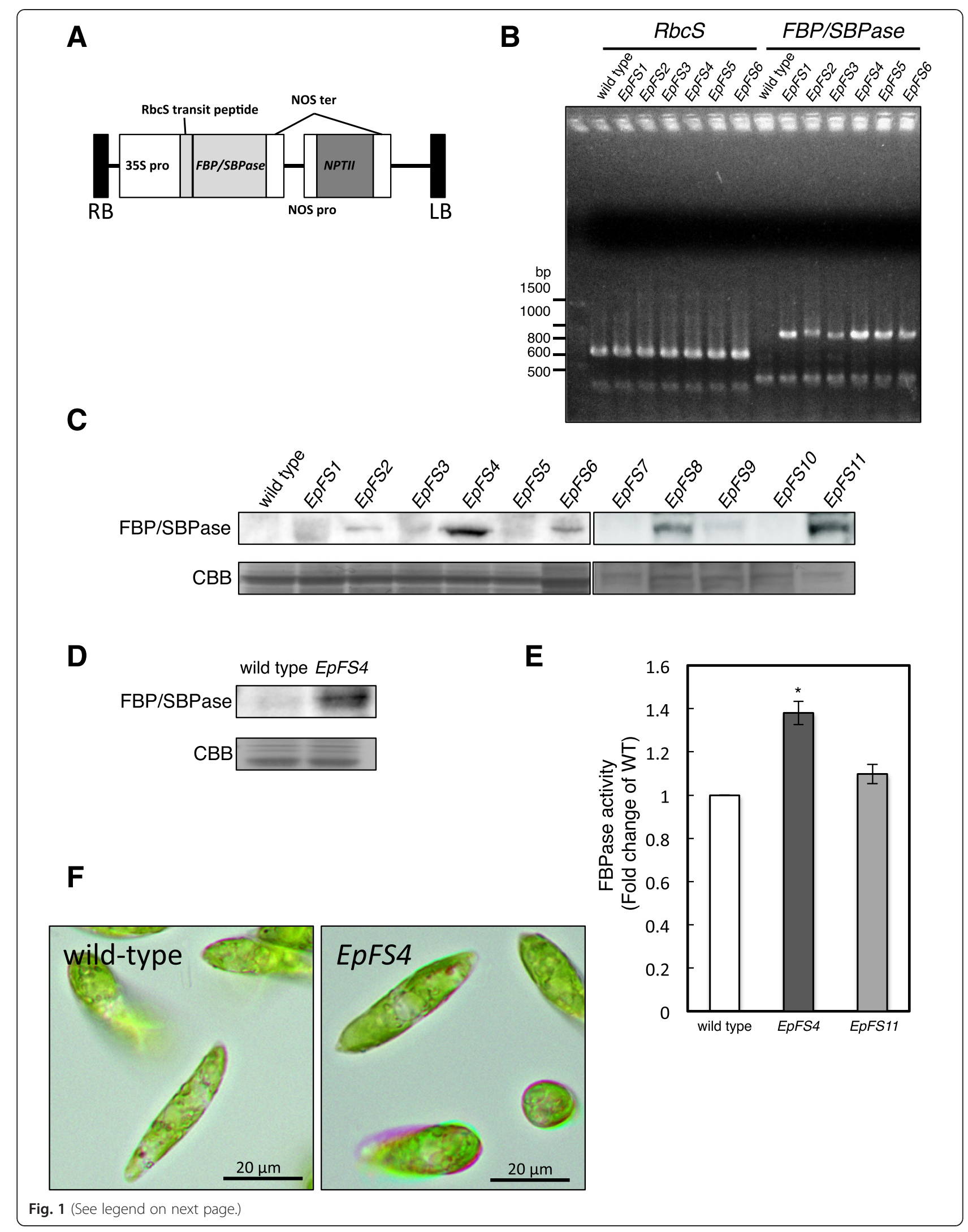


(See figure on previous page.)

Fig. 1 Isolation of transgenic E. gracilis cells having the FBP/SBPase gene. The construct structure of the gene using transformation of Euglena cells (a). Genomic PCR amplification of endogenous rbcS ( $637 \mathrm{bp}$ ) and FBP/SBPase (937 bp) genes from the wild-type and transgenic (EpFS) cell lines of E. gracilis (b). Western blot analysis of the crude extracts from wild-type and EPFS cell lines (c) and the intact chloroplastic fractions from wild-type and EpFS4 cells (d) using an antibody raised against the FBP/SBPase protein. Total FBPase activity in the stationary phase wild-type and EpFS cell lines grown under normal conditions (e). The photographs of wild-type and EpFS4 cells grown under normal conditions (f). Values are indicated as the mean \pm standard deviation for three individual experiments. An asterisk indicates significant differences from the wild-type E. gracilis cells $\left({ }^{*} P<0.05\right)$

1.1-fold higher in the EpFS4 and EpFS11 cell lines than in wild-type cells, respectively (Fig. 1e). The FBP/SBPase proteins were detected in chloroplasts isolated from the EpFS4 cells (Fig. 1d). These results clearly indicated that the FBP/ SBPase gene was successfully transformed into the EpFS cells, and the recombinant enzyme was then functionally expressed in the chloroplasts of Euglena cells after properly truncating the transit peptide.

\section{Photosynthesis, growth, and biomass production in EpFS cells under various growth conditions}

Cultivation conditions have been shown to greatly affect the growth and numerous chemical compositions of $E u$ glena cells [11-13]. We determined whether the ectopic expression of FBP/SBPase in Euglena cells affected photosynthesis, growth, and biomass (dry weight) and paramylon production under various growth conditions. Under normal conditions (100 $\mu \mathrm{mol}$ photons $\mathrm{m}^{-2} \mathrm{~s}^{-1}$ at $\left.0.04 \% \mathrm{CO}_{2}\right)$, only slight enhancements were observed in photosynthetic activity in the EpFS4 cells (data not shown). Concomitant with this, the cell volume of EpFS4 was significantly larger than that of wild-type cells (Table 1). While, no differences were observed in morphological and cell growth between wild-type and EpFS4 cells (Figs. 1f and 2a). Biomass and paramylon production was slightly higher in EpFS4 cells than in wild-type cells (Additional file 1: Tables S1 and Additional file 2: Table S2).

We then evaluated photosynthesis and the growth of EpFS4 cells under high light $\left(350 \mu \mathrm{mol}\right.$ photons $\mathrm{m}^{-2} \mathrm{~s}^{-1}$ at $\left.0.04 \% \mathrm{CO}_{2}\right)$ and/or high $\mathrm{CO}_{2}\left(0.3 \% \mathrm{CO}_{2}\right)$. The growth of wild-type and EpFS4 cells was markedly inhibited when grown under high light at $0.04 \% \mathrm{CO}_{2}$ (Additional file 3 : Figure S1). The cell density of EpFS4 line was higher than wild-type cells, although no significant differences were observed in the growth rates of wild-type and EpFS4 cells

Table 1 Cell volume of wild-type and EpFS4 cells under different growth conditions

\begin{tabular}{llll}
\hline $\begin{array}{l}\text { Light } \\
\text { intensity }\end{array}$ & $\begin{array}{l}100 \mu \mathrm{mol} \text { photons } \\
\mathrm{m}^{-2} \mathrm{~s}^{-1}\end{array}$ & $\begin{array}{l}350 \mu \mathrm{mol} \text { photons } \\
\mathrm{m}^{-2} \mathrm{~s}^{-1}\end{array}$ & $\begin{array}{l}350 \mu \mathrm{mol} \text { photons } \\
\mathrm{m}^{-2} \mathrm{~s}^{-1}\end{array}$ \\
\hline $\mathrm{CO}_{2}$ conc. & $0.04 \%$ & $0.04 \%$ & $0.30 \%$ \\
Wild type & $1626.9 \pm 25.9$ & $2011.0 \pm 228.6$ & $2980.9 \pm 414.6$ \\
EpFS4 & $1810.7 \pm 89.3^{*}$ & $2623.8 \pm 191.5^{*}$ & $3357.1 \pm 194.5^{*}$
\end{tabular}

Values are given in $\mathrm{fl}$ per cell and are the mean \pm standard deviation of the analysis of three to seven independent cultures. Asterisks indicate significant differences from the wild-type E. gracilis cells in each growth conditions $(* P<0.05)$
(Additional file 3: Figure S1). Under high light and high $\mathrm{CO}_{2}\left(350 \mu \mathrm{mol}\right.$ photons $\mathrm{m}^{-2} \mathrm{~s}^{-1}$ at $\left.0.3 \% \mathrm{CO}_{2}\right)$, the highlight-induced inhibition of growth in both wild-type and EpFS4 cells was markedly alleviated (Fig. 2b). Growth rate and cell volume were faster and larger in EpFS4 cells than in wild-type cells, respectively (Fig. 2b, Table 1). Furthermore, the enhancement of photosynthetic activity and significant accumulation of chlorophylls were observed in EpFS cell lines under high light and high $\mathrm{CO}_{2}$ (Fig. 3a, b). The productions of paramylon were significantly greater in EpFS cell lines than in wild-type cells (Table 2). Biomass productions were also approximately 1.3 - and 2.0-fold higher in transgenic cell lines than in wild-type cells (Table 3).

\section{Wax ester production and fatty acid profiling}

Because wax esters are synthesized by the degradation of paramylon in E. gracilis, the accumulation of paramylon may impact on their production. We evaluated the amount of a wax ester (myristyl myristate) and fatty acid content in wild-type and EpFS cell lines grown under normal conditions or high light and high $\mathrm{CO}_{2}$ and then placed onto anaerobiosis. After 24-h static culture under dark anaerobiosis, no significant difference was observed in the amount of the wax ester or fatty acid content between wild-type and EpFS4 cells grown under normal conditions (Additional file 4: Table S3 and Additional file 5: Table: S4). The amounts of wax ester in EpFS cell lines grown under high light and high $\mathrm{CO}_{2}$ were approximately 13- and 100-fold higher, respectively, than those in wildtype cells after the anaerobic incubation (Table 4). In addition, total fatty acid content was higher in EpFS cell lines reflecting the increased levels of FBPase activities than in wild-type cells, especially myristic acid (C14:0), which was approximately 2.5 - and 5-fold higher, respectively, than that in wild-type cells (Table 5).

\section{Discussion}

Critical matters that need to be resolved for the utilization of microalgae as a feasible energy source are their low productivity and the high-energy input required for their cultivation and processing. Bioprocess and metabolic engineering involving the introduction of appropriate genes appears to be a useful approach for overcoming some of these obstacles. We previously succeeded in generating high-yield transgenic tobacco and lettuce plants by 

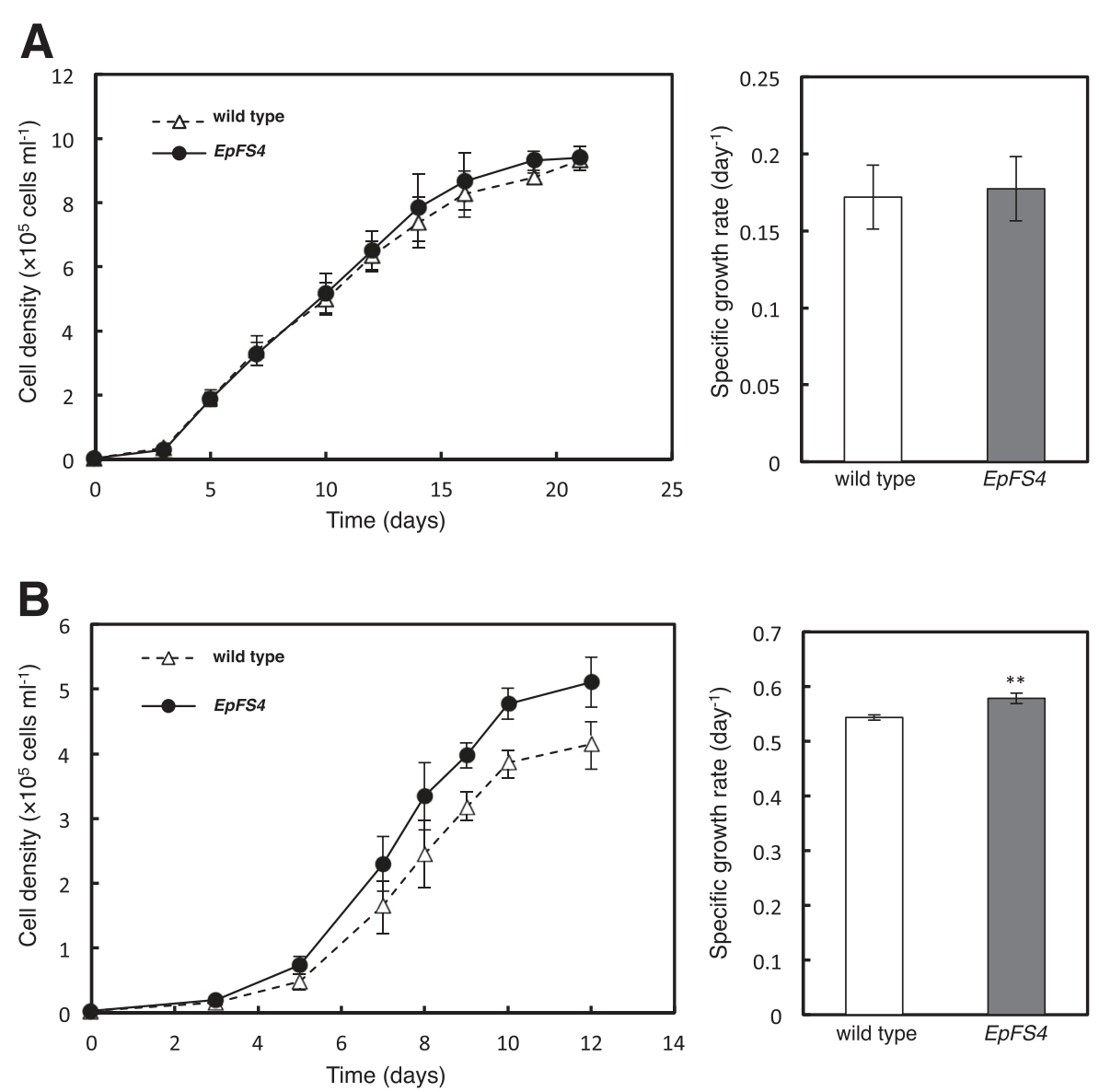

Fig. 2 Growth curves and growth rates of wild-type and EpFS4 cells grown under different cultivation conditions. Growth curves and growth rates of wild-type and EpFS4 cells grown under normal $\left(100 \mu \mathrm{mol}\right.$ photons $\mathrm{m}^{-2} \mathrm{~s}^{-1}$ at $\left.0.04 \% \mathrm{CO}_{2}\right)$ (a) and high light and high $\mathrm{CO}_{2}(350 \mu \mathrm{mol}$ photons $\mathrm{m}^{-2} \mathrm{~s}^{-1}$ at $\left.0.3 \% \mathrm{CO}_{2}\right)(\mathbf{b})$, respectively. Values are indicated as the mean \pm standard deviation for three to seven individual experiments. Asterisks indicate significant differences from the wild-type $E$. gracilis cells $(* * P<0.01)$

introducing cyanobacterial FBP/SBPase into their chloroplasts $[7,9,10]$. We established transgenic E. gracilis expressing cyanobacterial $\mathrm{FBP} / \mathrm{SBP}$ ase to enhance its photosynthetic activity in the present study, thereby increasing its productivity of biomass and/or a wax ester. We transformed the cyanobacterial FBP/SBPase gene into wild-type E. gracilis cells and generated EpFS cell lines. The transgene and expression of the FBP/SBPase protein as its mature form, except for the transit peptide, were detected in the EpFS cell lines. EpFS4 cells highly expressed mature FBP/SBPase in chloroplasts, and this was accompanied by a significant increase in FBPase activity. EpFS cell lines also showed phenotypes such as a larger cell volume and enhanced photosynthetic activity over wild-type cells, resulting in increased biomass and wax ester production under high light and high $\mathrm{CO}_{2}$. These results indicate that the cyanobacterial FBP/SBPase functioned in the transition of the rate-limiting step in the Calvin cycle of $E$. gracilis cells. However, several EpFS cell lines showed poor expression of FBP/SBPase protein (Fig. 1c). Poor expression of transgenes in Chlamydomonas has been reported; possible mechanisms for low expression of protein include gene silencing, inefficient transcription from heterologous promoters, improper RNA processing, mRNA instability, and instability of expressed proteins [3, 14]. Therefore, a variety of methods to improve the stability of transgene expression developed mainly with Chlamydomonas reinhardtii by the use of valuable endogenous promoters; inclusion of species-specific 5', 3', and intron sequences; and proper codon usage [3, 14, 15]. In this study, we used cauliflower mosaic virus 35S (CaMV35S) promoter and NOS terminator, generally used to express target genes. Therefore, it would be possible to refine the more stable expression of transgenes in E. gracilis after optimizing a variety of new genetic tools.

Although some enzymes involved in the Calvin cycle are present at levels well in excess of those required to sustain a continued rate of $\mathrm{CO}_{2}$ fixation, FBPase and SBPase levels are known to be markedly lower than those of other enzymes in the cycle [8]. In fact, the activity of FBPase 


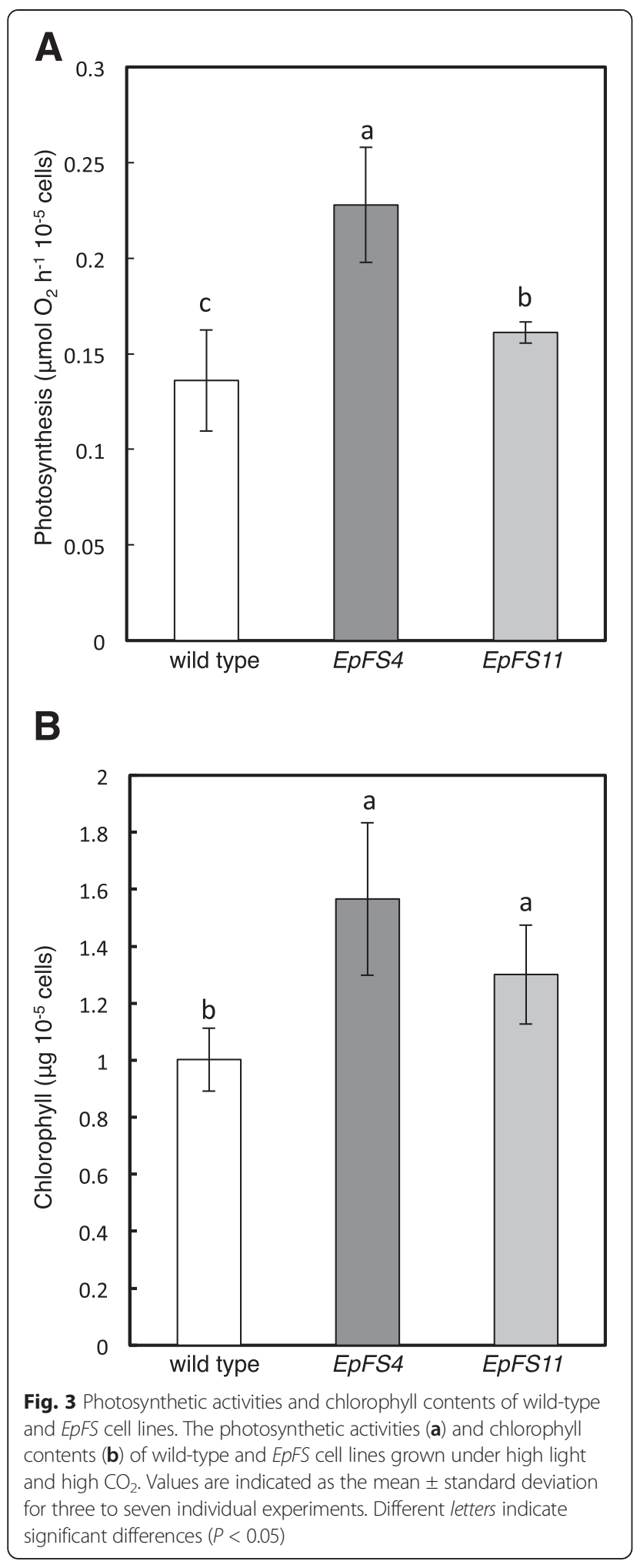

in E. gracilis cells was extremely lower than those of $\mathrm{NADP}^{+}$-dependent glyceraldehyde 3-phosphate dehydrogenase $\left(\mathrm{NADP}^{+}-\mathrm{GAPDH}\right)$ and phosphoribulokinase (PRK) (Additional file 6: Table S5). Fang et al.
Table 2 Paramylon content in wild-type and transgenic cell lines grown under high light and high $\mathrm{CO}_{2}$

\begin{tabular}{llll}
\hline Genotypes & $\mu \mathrm{g} 10^{-5}$ cells & $\mathrm{mg} \mathrm{g}^{-1} \mathrm{DW}$ & $\begin{array}{l}\text { Volumetric yield } \\
\left(\mathrm{mg} \mathrm{I}^{-1}\right)\end{array}$ \\
\hline Wild type & $38.4 \pm 5.8 \mathrm{~b}$ & $244.9 \pm 19.6 \mathrm{~b}$ & $79.7 \pm 26.0 \mathrm{c}$ \\
EpFS4 & $51.9 \pm 0.6 \mathrm{a}$ & $283.4 \pm 19.2 \mathrm{a}$ & $150.3 \pm 19.0 \mathrm{a}$ \\
EpFS11 & $49.6 \pm 9.9 \mathrm{a}$ & $265.8 \pm 20.6 \mathrm{a}$ & $116.2 \pm 24.8 \mathrm{~b}$ \\
\hline
\end{tabular}

Values are the mean \pm standard deviation of the analysis of 4 to 11 independent cultures. Different letters indicate significant differences $(P<0.05)$

recently reported that the Calvin cycle enzyme, SBPase from C. reinhardtii, was transformed into Dunaliella bardawil, and the transformant showed enhanced photosynthesis and increased glycerol biosynthesis [16]. These findings indicate that FBPase and SBPase in the Calvin cycle are important strategic positions that enhance the photosynthetic capacity of photosynthetic microalgae.

We previously reported that transgenic plants in which the capacity of the Calvin cycle was enhanced grew faster than wild-type tobacco plants under $400 \mu \mathrm{mol}$ photons $\mathrm{m}^{-2} \mathrm{~s}^{-1}$, but not under $100 \mu \mathrm{mol}$ photons $\mathrm{m}^{-2} \mathrm{~s}^{-1}$ $[7,9,10,17]$. Photosynthetic activity was significantly higher in transgenic plants than in wild-type plants at irradiances above $200 \mu \mathrm{mol}$ photons $\mathrm{m}^{-2} \mathrm{~s}^{-1}$. Under low light, photosynthetic $\mathrm{CO}_{2}$ assimilation was not limited by the capacity of the Calvin cycle but was by that of photosynthetic electron transport [18]. Accordingly, transgenic plants expressing $\mathrm{FBP} / \mathrm{SBP}$ ase showed the phenotype, except for under $100 \mu \mathrm{mol}$ photons $\mathrm{m}^{-2} \mathrm{~s}^{-1}$. Clear phenotypes were also observed in EpFS cell lines under high light and high $\mathrm{CO}_{2}$. Under $100 \mu \mathrm{mol}$ photons $\mathrm{m}^{-2} \mathrm{~s}^{-1}$, the volume of EpFS4 cells was significantly higher (Table 1), while the growth rate was almost the same as that of wild-type cells (Fig. 2a). Under high light and high $\mathrm{CO}_{2}$, both the cell volume and growth rate of EpFS4 cells were higher than those of wild-type cells (Fig. 2b, Table 1). On the other hand, the growth of wild-type and EpFS4 cells was inhibited under high light at atmospheric $\mathrm{CO}_{2}$, although the cell density of EpFS4 cells was higher than wild-type cells (Additional file 3: Figure S1). These results suggest that wild-type cells could not consume excess reducing energy from the photosynthetic electron transport system under high light at atmospheric $\mathrm{CO}_{2}$. One of the reasons for the

Table 3 Biomass production of wild-type and transgenic cell lines grown under high light and high $\mathrm{CO}_{2}$

\begin{tabular}{ll}
\hline Genotypes & $\mathrm{mg}$ of DW $\mathrm{I}^{-1}$ \\
\hline Wild type & $321.1 \pm 117.7 \mathrm{c}$ \\
EpFS4 & $631.1 \pm 89.9 \mathrm{a}$ \\
EpFS11 & $430.3 \pm 65.5 \mathrm{~b}$ \\
\hline
\end{tabular}

Values are the mean \pm standard deviation of the analysis of five to eight independent cultures. Different letters indicate significant differences $(P<0.05)$ 
Table 4 Wax ester (C28) content in wild-type and transgenic cell lines after anaerobic incubation

\begin{tabular}{lll}
\hline Genotypes & $\mathrm{ng} 10^{-5}$ cells & $\mathrm{ng} \mathrm{mg}^{-1} \mathrm{DW}$ \\
\hline Wild type & $0.6 \pm 0.2 \mathrm{c}$ & $4.4 \pm 1.5 \mathrm{c}$ \\
EpFS4 & $65.2 \pm 17.3 \mathrm{a}$ & $418.3 \pm 92.0 \mathrm{a}$ \\
EpFS11 & $10.4 \pm 1.8 \mathrm{~b}$ & $56.8 \pm 11.3 \mathrm{~b}$
\end{tabular}

The wild-type and transgenic cell lines grown under high light and high $\mathrm{CO}_{2}$ were placed on anaerobiosis for $24 \mathrm{~h}$. Values are the mean \pm standard deviation of the analysis of two to four independent cultures. Different letters indicate significant differences $(P<0.05)$

tolerance of EpFS4 cells to high light may be that these cells are able to consume an excess of reducing energy due to the enhanced capacity of the Calvin cycle. In support of this, the inhibition of growth in wild-type cells grown under high light was recovered by supplementation with high $\mathrm{CO}_{2}$ (Fig. 2b). These results suggest that the expression of $\mathrm{FBP} / \mathrm{SBP}$ ase leads to an increase in biomass production in E. gracilis cells under conditions in which the capacity of the Calvin cycle is a limiting factor for photosynthesis.

When Euglena grown aerobically is placed under anaerobic conditions, paramylon is rapidly converted into wax esters by wax ester fermentation [4]. A biochemical analysis has been conducted on the enzymes involved in the biosynthesis of fatty acids and wax esters in Euglena $[5,19,20]$; however, the regulatory mechanisms underlying the dynamic shift in wax ester fermentation remain unclear. Under high light and high $\mathrm{CO}_{2}$, the content of paramylon was significantly higher in $E p F S$ cell lines than in wild-type cells, whereas no significant differences were observed in the content of the wax ester under aerobic conditions between wildtype and EpFS cells (data not shown). After 24-h static culture under dark anaerobiosis, the productions of the wax ester and myristic acid in EpFS cell lines grown under high light and high $\mathrm{CO}_{2}$ were greatly higher than that in wild-type cells (Table 4). In addition, increased levels of the wax ester and myristic acid between EpFS4 and EpFS11 were reflected in their FBPase activities. These results clearly indicated that the enhancement in photosynthetic capacity under aerobic conditions led to an increase in wax ester production under anaerobic conditions in Euglena cells. Previous studies identified pyruvate:$\mathrm{NADP}^{+}$oxidoreductase as a rate limiting step in wax ester fermentation because its activity was inhibited by oxygen [21,22]. These findings suggest that accumulation of paramylon and/or various metabolites, such as intermediates of the Calvin cycle, paramylon precursors, and pyruvate, as a substrate for pyruvate:NADP ${ }^{+}$ oxidoreductase, by enhancements in photosynthetic capacity, is one of the key metabolic factors for the biosynthesis of fatty acids and wax esters.

Inui et al. previously showed that all carbons in wax esters were supplied from paramylon, and approximately $40 \%$ of paramylon was estimated to be converted to wax esters in Euglena cells heterotrophically grown in an organic carbon-rich medium [4]. In the present study, the amount of paramylon that accumulated under aerobic conditions was reduced by approximately $30 \%$ after anaerobic incubation (Additional file 7: Table S6). However, the increase observed in wax ester production was not similar to the decrease in paramylon in wild-type and EpFS4 cells photoautotrophically grown in an organic carbon-free medium. A recent metabolic profiling analysis in Euglena clearly indicated a dynamic shift in the central metabolic status including glycolysis, amino acid, and lipid production in response to aerobic/anaerobic conditions [13]. Therefore, organic carbons derived from paramylon are expected to be utilized not only for the synthesis of wax esters but also for numerous metabolic pathways in photoautotrophically grown cells under anaerobic conditions. When Euglena cells grow under heterotrophic conditions in an organic carbon-rich medium, the synthesis of wax esters from paramylon may be higher than that in photoautotrophically grown Euglena cells because the heterotrophic growth medium contained a large amount of available carbons for numerous metabolic pathways, such as amino acids and protein synthesis. Thus, elucidating the underlying regulatory mechanism and modulation of wax ester fermentation in photoautotrophically grown Euglena cells is needed for further increases in the production of wax esters by E. gracilis cells.

Table 5 Fatty acid content in wild-type and transgenic cell lines after anaerobic incubation

\begin{tabular}{|c|c|c|c|c|c|c|}
\hline Chain length & Wild type & EpFS4 & EpFS11 & Wild type & EpFS4 & EpFS11 \\
\hline & & (ng $10^{-5}$ cells) & & & (ng $\mathrm{mg}^{-1} \mathrm{DW}$ ) & \\
\hline C12 & $15.2 \pm 6.8 b$ & $27.2 \pm 2.9 \mathrm{a}$ & $29.1 \pm 1.6 \mathrm{a}$ & $106.6 \pm 38.0 b$ & $176.9 \pm 28.9 a$ & $164.6 \pm 19.6 \mathrm{a}$ \\
\hline C14 & $57.0 \pm 5.3 c$ & $318.9 \pm 32.3 a$ & $158.3 \pm 33.3 b$ & $424.7 \pm 67.6 c$ & $2072.8 \pm 322.6 \mathrm{a}$ & $963.5 \pm 372.3 b$ \\
\hline C15 & $14.7 \pm 1.8$ & $11.3 \pm 0.4$ & $9.7 \pm 2.7$ & $105.6 \pm 16.2$ & $73.0 \pm 6.6$ & $49.6 \pm 19.2$ \\
\hline C16 & $256.6 \pm 43.6 b$ & $348.6 \pm 10.3 a$ & $301.5 \pm 61.3 b$ & $1828.2 \pm 169.1 b$ & $2260.5 \pm 187.2 \mathrm{a}$ & $2040.3 \pm 276.5 b$ \\
\hline C18 & $46.1 \pm 8.4$ & $30.9 \pm 2.5$ & $29.7 \pm 3.6$ & $332.5 \pm 71.5$ & $200.4 \pm 17.8$ & $186.6 \pm 50.0$ \\
\hline
\end{tabular}

The wild-type and EpFS4 cells grown under high light and high $\mathrm{CO}_{2}$ were placed on anaerobiosis for $24 \mathrm{~h}$. Values are the mean \pm standard deviation of the analysis of three to six independent cultures. Different letters indicate significant differences $(P<0.05)$ 


\section{Conclusions}

In this work, we established transgenic E. gracilis expressing cyanobacterial $\mathrm{FBP} / \mathrm{SBP}$ ase to enhance its photosynthetic activity. The results of the present study demonstrated that enhancements in photosynthetic capacity facilitated biomass and wax ester production in photoautotrophically grown E. gracilis, and our strategy paves the way to increased photosynthesis and biomass production in a wide range of photosynthetic microalgae. Although further understanding of the mechanisms underlying wax ester biosynthesis and optimization of new genetic tools and cultivation systems for $E$. gracilis are required, this is the first step toward the utilization of E. gracilis as a sustainable source for biofuel production.

\section{Methods}

Cell strain and growth condition

Euglena gracilis Z (NIES-48) was cultured photoautotrophically in Cramer-Myers medium [23] on a rotary shaker $(120 \mathrm{rpm})$ under continuous light $(100 \mu \mathrm{mol}$ photons $\left.\mathrm{m}^{-2} \mathrm{~s}^{-1}\right)$ at $26^{\circ} \mathrm{C}$.

\section{Plasmid construction}

To generate transgenic E. gracilis, pRI101-AN, which has the NPT II gene cassette, was used to construct plasmids. Cyanobacterial FBP/SBPase fused with the transit peptide of the tomato $r b c S 3 C$ gene was amplified by PCR from a previously reported plasmid [7] using the following primer set: 5'-CATATGGCTTCTT CAGTAATGTCC-3' and 5'-GAATTCTTAACGGAGGC TAACCGTTTTGA-3' (Nde I and EcoR I site italicized). The amplified DNA fragment was ligated into pT7Blue (Novagen, Madison, WI, USA) and then digested with Nde I and $E c o$ R I. The Nde I-EcoR I DNA fragment was cloned into the Nde I-EcoR I sites of pRI101-AN, located downstream of the CaMV35S promoter, to generate pRI101-35S: $S L-r b c S-f b p / s b p a s e$. Regarding the transformation, the LB-RB region of pRI101-35S: SL-rbcS-fbp/sbpase containing the FBP/SBPase and NPT II genes was amplified by PCR using the following primer set: LB primer 5 '-TGGCAGGA TATATTGTAAACAAATTGACGC-3' and RB primer 5'-GTTTACCCGCCAATAGTCAAACACTGATAG-3'. The amplified DNA fragments (approximately $4.8 \mathrm{Kbp}$ ) were purified and used for the transformation.

\section{Transformation of E. gracilis by microprojectile bombardment}

Approximately $1 \times 10^{7}$ E. gracilis cells in the logarithmic growth phase were harvested by centrifugation $(3000 \times g$, $5 \mathrm{~min}, 25^{\circ} \mathrm{C}$ ), washed with $20 \mathrm{ml}$ of distilled water, and resuspended in $2 \mathrm{ml}$ of distilled water. The collected cells were placed onto $0.22-\mu \mathrm{m}$ membrane filters (Millipore, Bedford, MA, USA) under a gentle vacuum, and the filters were then transferred onto $\mathrm{CM}$ agar plates. The cells were incubated at $26^{\circ} \mathrm{C}$ for $24 \mathrm{~h}$ in the dark.

Regarding microprojectile bombardment, $0.25-\mu \mathrm{m}$ gold nanoparticles (BBI Solutions, Cardiff, UK) were coated with the amplified DNA fragment. One milliliter of gold nanoparticle solution was centrifuged, washed twice with $1 \mathrm{ml}$ of $\mathrm{EtOH}$, and then washed once with $1 \mathrm{ml}$ of distilled water. Gold nanoparticles were resuspended in $100 \mu \mathrm{l}$ of distilled water and $6 \mu \mathrm{g}$ of the amplified DNA fragment, $100 \mu \mathrm{l}$ of $2.5 \mathrm{M} \mathrm{CaCl}_{2}$, and $40 \mu \mathrm{l}$ of $0.1 \mathrm{M}$ spermidine were added. The mixture was blended continuously for $20 \mathrm{~min}$ at $4{ }^{\circ} \mathrm{C}, 200 \mu \mathrm{l}$ of $\mathrm{EtOH}$ was added, and the mixture was then centrifuged $\left(10,000 \times g, 1 \mathrm{~min}, 4{ }^{\circ} \mathrm{C}\right)$. The pellet was washed three times with $200 \mu \mathrm{l} \mathrm{EtOH}$ and centrifuged for $1 \mathrm{~min}$ at $10,000 \times g$. The DNA-coated nanoparticles were resuspended in $60 \mu \mathrm{l} \mathrm{EtOH}\left(6 \mu \mathrm{l}\right.$ shot $\left.^{-1}\right)$ and maintained at $4{ }^{\circ} \mathrm{C}$. The transformation of wild-type E. gracilis cells was performed using the Bio-Rad PDS1000/He system (Bio-Rad, Hercules, CA, USA). DNAcoated nanoparticles were spread on a macrocarrier, which was placed in a macrocarrier holder. A rupture disc pressure of $900 \mathrm{psi}$ and a target distance of $9 \mathrm{~cm}$ were used for bombardments. After microprojectile bombardment, the cells were washed off from the membrane filter with $2 \mathrm{ml}$ of CM liquid medium and cultured for $24 \mathrm{~h}$ under continuous light. Cells were collected, plated onto a $1.5 \%(w / v)$ agar CM plate $\left(\sim 1 \times 10^{5}\right.$ plate 1$)$ containing $250 \mu \mathrm{g} \mathrm{ml}^{-1}$ paromomycin, and incubated at $26{ }^{\circ} \mathrm{C}$ under a continuous light intensity of $100 \mu \mathrm{mol}$ photons $\mathrm{m}^{-2} \mathrm{~s}^{-1}$ until antibioticresistant colonies appeared. The transformed colonies were maintained on $\mathrm{CM}$ agar medium containing 250 $\mu \mathrm{g} \mathrm{ml} l^{-1}$ paromomycin.

\section{Genomic DNA extraction from E. gracilis}

Cells were harvested and suspended in $5 \mathrm{ml}$ of extraction buffer containing $50 \mathrm{mM}$ Tris- $\mathrm{HCl}(\mathrm{pH} 9.0), 100 \mathrm{mM}$ $\mathrm{NaCl}, 10 \mathrm{mM}$ EDTA, $2 \%(w / v)$ SDS, and $200 \mu \mathrm{g} \mathrm{ml}^{-1}$ Proteinase $\mathrm{K}$. After the cell suspensions were extracted with phenol/chloroform/isoamyl alcohol and treated with RNase A, genomic DNA was recovered by ethanol precipitation following phenol/chloroform/isoamyl alcohol treatments.

\section{PCR confirmation of transformation}

Genomic PCR was performed with isolated genomic DNA (approximately $50 \mathrm{ng}$ ) as a template and the following primer sets: Eu rbcS-NF 5'-CTCTCATTACGATGCCATTT GAC-3', Eu rbcS-631R 5'-GGTGTTGTCATTGGCGATG AAAGC-3', 35S-60F 5' -TATCTCCACTGACGTAAG GG-3', and FI-597R 5' -ACCATCGCTGATCAGACGG-3'. PCR amplification was performed for 40 cycles of $95^{\circ} \mathrm{C}$ for $30 \mathrm{~s}, 55{ }^{\circ} \mathrm{C}$ for $30 \mathrm{~s}$, and $72{ }^{\circ} \mathrm{C}$ for $60 \mathrm{~s}$, followed by $72{ }^{\circ} \mathrm{C}$ for $10 \mathrm{~min}$. 


\section{Western blotting analysis}

Proteins were separated by $10 \%(w / v)$ NuPAGE $^{\oplus}$ Gel (Invitrogen, Carlsbad, CA, USA) and blotted onto a PVDF membrane (GE Healthcare, Little Chalfont, UK) using the Xcell II $^{\mathrm{m}}$ Blot Module (Invitrogen, Carlsbad, CA, USA). The FBP/SBPase protein was detected using a mouse monoclonal FBP/SBPase antibody [24] and anti-mouse IgG-horseradish peroxidase (HRP) conjugate (Bio-Rad, Hercules, CA, USA) as the secondary antibody. Protein bands were detected using the enhanced chemiluminescence detection system (GE Healthcare, Little Chalfont, UK).

\section{Isolation of chloroplasts from $E$. gracilis}

All procedures were conducted at $4{ }^{\circ} \mathrm{C}$. E. gracilis cells were gently ground with a small amount of sea sand in $50 \mathrm{ml}$ of cold grinding buffer containing $0.33 \mathrm{M}$ sorbitol, $50 \mathrm{mM}$ Tricine- $\mathrm{KOH}$ (pH 7.5), $1 \mathrm{mM} \mathrm{MgCl}_{2}, 2 \mathrm{mM}$ EDTA, and $10 \mathrm{mM} \mathrm{NaCl}$. The homogenate was centrifuged at $300 \times g$ for $5 \mathrm{~min}$. The resultant supernatant was centrifuged at $1500 \times g$ for $10 \mathrm{~min}$ to obtain the crude chloroplast fraction. Pelleted crude chloroplasts were resuspended in a small volume $(\sim 4 \mathrm{ml})$ of grinding buffer. The suspension was layered on top of the Percoll solution, which consisted of $20 \mathrm{ml}$ of grinding buffer containing the $40 \%(v / v)$ and $75 \%(v / v)$ Percoll solutions, and centrifuged for $10 \mathrm{~min}$ at $2500 \times g$. Intact chloroplasts were recovered as a band at the interface of the $40 \%$ and $75 \%$ Percoll layers. They were collected using a pipette, and the suspension was washed with grinding buffer (10 volumes of chloroplasts suspension) to remove Percoll. Pelleted chloroplasts were resuspended in a small volume of the rupture buffer containing $25 \mathrm{mM}$ Tricine- $\mathrm{KOH}$ (pH 7.5), $1 \mathrm{mM} \mathrm{MgCl}_{2}, 5 \mathrm{mM} \mathrm{NaCl}$, and $0.5 \%$ Triton $\mathrm{X}-100$. Aliquots of fractions were subjected to Western blot analysis.

\section{Determination of chlorophyll content}

Chlorophyll was extracted from E. gracilis cells with $80 \%$ $(v / v)$ acetone and measured by the method of Arnon [25].

\section{Measurements of cell density and cell volume}

Stock cultures of wild-type and transgenic E. gracilis cells were grown in CM medium at stationary phase as a pre-culture, and $1.5 \times 10^{6}$ cells were then placed into 1000-ml baffle-flasks containing $500 \mathrm{ml}$ fresh CM medium. The cultures were grown under normal light (100 $\mu$ mol photons $\mathrm{m}^{-2} \mathrm{~s}^{-1}$ ), high light $(350 \mu \mathrm{mol}$ photons $\left.\mathrm{m}^{-2} \mathrm{~s}^{-1}\right)$, and high light/high $\mathrm{CO}_{2}(350 \mu \mathrm{mol}$ photons $\left.\mathrm{m}^{-2} \mathrm{~s}^{-1}, 0.3 \% \mathrm{CO}_{2}\right)$ with mild agitation $(120 \mathrm{rpm})$ at $26{ }^{\circ} \mathrm{C}$ in the plant growth chamber, BioTRON NC350 (Nippon Medical \& Chemical Instruments Co., Ltd., Osaka, Japan). Cell density and volume were measured using the CASY Cell Counter and Analyzer System
(Roche Applied Science, Basel, Switzerland). Specific growth rates $(\mu)$ were calculated from the slope of natural log-phase according to the formula: $\mu=\ln \left(N_{2} / N_{1}\right)$ / $\left(t_{2}-t_{1}\right)$, where $N_{1}$ and $N_{2}$ represent cell density at times $t_{1}$ and $t_{2}$ [26]. At the late log-phase, cells were collected by centrifugation and then freeze-dried to analyze the contents of paramylon, wax esters, and fatty acids. Anaerobiosis was applied by bubbling $N_{2}$ to $30 \mathrm{ml}$ of cells grown to the late log-phase, and anaerobic cells were then placed into the dark for $24 \mathrm{~h}$.

\section{Assay of enzyme activities}

E. gracilis cells $(20 \mathrm{ml})$ in the late log-phase were harvested by centrifugation $(8000 \times g$ for $5 \mathrm{~min}$ ); resuspended in 100 $\mathrm{mM}$ Tris- $\mathrm{HCl}$ (pH 8.0) buffer containing $10 \mathrm{mM} \mathrm{MgCl}_{2}, 1$ mM EDTA, $2.5 \mathrm{mM}$ DTT, $1 \mathrm{mM}$ GSH, and $0.1 \%(v / v)$ Triton X-100; and sonicated for a total of $1 \mathrm{~min}$ with five intervals of $10 \mathrm{~s}$ each. FBPase activity was assayed as described previously [7].

\section{Measurements of photosynthetic activity}

The uptake and evolution of $\mathrm{O}_{2}$ were measured with an oxygen electrode (Hansatech Instruments Ltd., King's Lynn, UK). The reaction mixture $(2 \mathrm{ml})$ containing CM medium, $1 \mathrm{mM} \mathrm{NaHCO}$, and an arbitrary number of $E$. gracilis cells was illuminated (approximately $300 \mu \mathrm{mol}$ photons $\mathrm{m}^{-2} \mathrm{~s}^{-1}$ ) with white light at $26^{\circ} \mathrm{C}$.

\section{Analysis of paramylon content}

Approximately 10-20 mg of freeze-dried E. gracilis cells were suspended in $10 \mathrm{ml}$ of acetone. The mixture was sonicated and vortexed for $1 \mathrm{~min}$ and then centrifuged at $11,000 \times g$ for $5 \mathrm{~min}$. The supernatant was discarded, and these steps were repeated two times. After the pellet was resuspended with $10 \mathrm{ml}$ of $1 \%(w / v)$ SDS and vortexed for $1 \mathrm{~min}$, the cell suspension was heated in boiling water for $30 \mathrm{~min}$ and centrifuged at $11,000 \times g$ for 15 min. After the supernatant was discarded, $1 \mathrm{ml}$ of $0.1 \%$ $(w / v)$ SDS was added to the pellet and vortexed for 1 min. After centrifugation $(11,000 \times g$ for $5 \mathrm{~min})$, the pellet was washed with MilliQ water and resuspended in $10 \mathrm{ml}$ of $1 \mathrm{~N} \mathrm{NaOH}$. To determine the amount of free glucose in the cell suspension, a $0.5-\mathrm{ml}$ aliquot was mixed with $0.5 \mathrm{ml}$ of $5 \%$ phenol and $2.5 \mathrm{ml}$ of concentrated $\mathrm{H}_{2} \mathrm{SO}_{4}$. After being incubated at $30{ }^{\circ} \mathrm{C}$ for $30 \mathrm{~min}$, absorbance at $490 \mathrm{~nm}$ was determined. Absorbance was transformed to glucose equivalents using a standard calibration curve.

\section{Fatty acid and wax ester measurements}

Euglena cells were harvested (1-ml medium) and fatty acid methyl esters (FAMEs) were prepared using a fatty acid methylation kit following the manufacturer's instructions 
(Nacalai Tesque, Kyoto, Japan). The resulting FAMEs were then purified with a silica cartridge column and finally eluted with $3 \mathrm{ml}$ of elution solution (n-hexane:methyl acetate $=94: 2(v / v))$ supplied by the manufacturer (Nacalai Tesque, Kyoto, Japan). Extraction of the wax ester was performed using the method by Inui et al. [4] with slight modifications. Briefly, the collected cells were agitated vigorously with a $2.5-\mathrm{ml}$ mixture of chloroform:methanol:water $=10: 20: 8(v / v)$ and centrifuged to remove cell debris. The organic phase was dried with a rotary evaporator and resuspended in the elution solution. One microliter of each sample was analyzed using GCMS-QP2010 Ultra (Shimadzu, Kyoto, Japan) equipped with a DB-5ms capillary GC column $(0.25 \mathrm{~mm} \times 30 \mathrm{~m}, 0.25-\mu \mathrm{m}$ thickness, Agilent, Santa Clara, CA, USA) coated with $5 \%$ phenyl siloxane. The temperature program was as follows: the initial oven temperature was held at $60{ }^{\circ} \mathrm{C}$ for $0.5 \mathrm{~min}$, then programmed to increase at $240{ }^{\circ} \mathrm{C} \mathrm{min}^{-1}$ to $250{ }^{\circ} \mathrm{C}$, and was held for $15 \mathrm{~min}$. The carrier gas was helium with a constant linear velocity of $40 \mathrm{~cm} \mathrm{sec}{ }^{-1}$. The detector temperature was $250{ }^{\circ} \mathrm{C}$. All data acquisition and processing were performed with the GC-MS Solution Software (Shimadzu, Kyoto, Japan).

\section{Data analysis}

Significance of differences between data sets was evaluated by $t$-test. Calculations were carried out with Microsoft Excel software.

\section{Additional files}

Additional file 1: Table S1. Paramylon content in wild-type and EpFS4 cells grown under normal conditions.

Additional file 2: Table S2. Biomass production of wild-type and EpFS4 cells grown under normal conditions.

Additional file 3: Figure S1. Growth curves and growth rates of wild-type and EpFS4 cells grown under high light at $0.04 \% \mathrm{CO}_{2}$. Growth curves (left) and growth rates (right) of wild-type and EpFS4 cells. Values are indicated as the mean \pm standard deviation for three to seven individual experiments.

Additional file 4: Table S3. Wax ester (C28) content in wild-type and EpFS4 cells grown under normal conditions after anaerobic incubation.

Additional file 5: Table S4. Fatty acid content in wild-type and EpFS4 cells grown under normal conditions after anaerobic incubation.

Additional file 6: Table S5. The FBPase, PRK, and NADP+-GAPDH activities in wild-type cells grown under normal conditions.

Additional file 7: Table S6. Paramylon content in wild-type and EpFS4 cells grown under different growth conditions after anaerobic incubation.

\section{Abbreviations}

FBP/SBPase: Fructose-1,6-/sedoheptulose-1,7-bisphosphatase: FBPase: Fructose-1,6-bisphosphatase; SBPase: Sedoheptulose-1,7-bisphosphatase; rbcS: Rubisco small subunit; CaMV35S promoter: Cauliflower mosaic virus 355 promoter; NPT II: Neomycin phosphotransferase II; NOS: Nopaline synthase; NADP ${ }^{+}$-GAPDH: NADP ${ }^{+}$-dependent glyceraldehyde 3-phosphate dehydrogenase; PRK: Phosphoribulokinase.
Competing interests

The authors declare that they have no competing interests.

\section{Authors' contributions}

TO, AK, and AM carried out major experiments containing the cell cultivation, molecular genetic studies, and biochemical assays. TI and TM participated in the wax ester and fatty acid analysis. TO and MT drafted the manuscript. HS, EY, and KS supported biochemical assay and helped to draft the manuscript. TM, TI, and SS edited the manuscript. TI, MT, and SS conceived of the study and participated in its design and coordination. All authors read and approved the final manuscript.

\section{Acknowledgements}

We thank Yuki Yamaguchi (Shimane University) for technical support with GC mass spectrometry measurements.

\section{Author details}

'Department of Advanced Bioscience, Faculty of Agriculture, Kinki University, 3327-204 Nakamachi, Nara 631-8505, Japan. ${ }^{2}$ Core Research for Evolutional Science and Technology (CREST), Japan Science and Technology Agency (JST), Chiyoda-ku, Tokyo 102-0076, Japan. ${ }^{3}$ Faculty of Life and Environmental Science, Shimane University, 1060 Nishikawatsu, Matsue, Shimane 690-8504, Japan. ${ }^{4}$ euglena Co., Ltd., 31F lidabashi First Tower, 2-6-1 Koraku, Bunkyo-ku, Tokyo 112-0004, Japan.

Received: 22 November 2014 Accepted: 22 May 2015

Published online: 30 May 2015

\section{References}

1. Stephens E, Ross IL, King Z, Mussgnug JH, Kruse O, Posten C, et al. An economic and technical evaluation of microalgal biofuels. Nat Biotech. 2010;28:126-8.

2. Gimpel JA, Specht EA, Georgianna DR, Mayfield SP. Advances in microalgae engineering and synthetic biology applications for biofuel production. Curr Opin Chem Biol. 2013;17:489-95.

3. Radakovits R, Jinkerson RE, Darzins A, Posewitz MC. Genetic engineering of algae for enhanced biofuel production. Eukaryot Cell. 2010;9:486-501.

4. Inui H, Miyatake K, Nakano Y, Kitaoka S. Wax ester fermentation in Euglena gracilis. FEBS Lett. 1982;150:89-93.

5. Inui H, Miyatake K, Nakano Y, Kitaoka S. Fatty acid synthesis in mitochondria of Euglena gracilis. Eur J Biochem. 1984;142:121-6.

6. Buetow DE. The mitochondrion. In: Buetow DE, editor. The Biology of Euglena. Volume IV. New York: Academic; 1989. p. 247-314.

7. Miyagawa Y, Tamoi M, Shigeoka S. Overexpression of a cyanobacterial fructose-1,6-/sedoheptulose-1,7-bisphosphatase in tobacco enhances photosynthesis and growth. Nat Biotechnol. 2001;19:965-9.

8. Woodrow IE, Mott KA. Modeling $C_{3}$ photosynthesis: a sensitivity analysis of the photosynthetic carbon-reduction cycle. Planta. 1993;191:421-32.

9. Yabuta Y, Tamoi M, Yamamoto K, Tomizawa K, Yokota A, Shigeoka S. Molecular designing of photosynthesis-elevated chloroplasts for mass accumulation of a foreign protein. Plant Cell Physiol. 2008;49:375-85.

10. Ichikawa Y, Tamoi M, Sakuyama H, Maruta T, Ashida H, Yokota A, et al. Generation of transplastomic lettuce with enhanced growth and high yield. GM Crops. 2010;1:322-6.

11. Barsanti L, Vismara R, Passarelli V, Gualtieri P. Paramylon ( $\beta$-1,3-glucan) content in wild type and WZSL mutant of Euglena gracilis. Effects of growth conditions. J Appl Phycol. 2001;13:59-65.

12. Fujita T, Aoyagi H, Ogbonna JC, Tanaka H. Effect of mixed organic substrate on a-tocopherol production by Euglena gracilis in photoheterotrophic culture. Appl Microbiol Biotechnol. 2008;79:371-8.

13. Matsuda F, Hayashi M, Kondo A. Comparative profiling analysis of central metabolites in Euglena gracilis under various cultivation conditions. Biosci Biotechnol Biochem. 2011;75:2253-6.

14. Kumar A, Falcao VR, Sayre RT. Evaluating nuclear transgene expression systems in Chlamydomonas reinhardtii. Algal Res. 2013;2:321-32.

15. Eichler-Stahlberg A, Weisheit W, Ruecker O, Heitzer M. Strategies to facilitate transgene expression in Chlamydomonas reinhardtii. Planta. 2009;229:873-83.

16. Fang L, Lin HX, Low CS, Wu MH, Chow Y, Lee YK. Expression of the Chlamydomonas reinhardtii Sedoheptulose-1, 7-bisphosphatase in Dunaliella bardawil leads to enhanced photosynthesis and increased glycerol production. Plant Biotechnol J. 2012;10:1129-35. 
17. Tamoi M, Nagaoka M, Miyagawa Y, Shigeoka S. Contribution of fructose-1,6-bisphosphatase and sedoheptulose-1,7-bisphosphatase to the photosynthetic rate and carbonflow in the Calvin cycle in transgenic plants. Plant Cell Physiol. 2006;47:380-90.

18. Farquhar GD, von Caemmerer $\mathrm{S}$, Berry JA. A biochemical model of photosynthetic $\mathrm{CO}_{2}$ assimilation in leaves of $\mathrm{C}_{3}$ species. Planta. 1980;149:78-90.

19. Hoffmeister M, Piotrowski M, Nowitzki U, Martin W. Mitochondrial trans-2-enoylCoA reductase of wax ester fermentation from Euglena gracilis defines a new family of enzymes involved in lipid synthesis. J Biol Chem. 2005;280:4329-38.

20. Teerawanichpan P, Qui X. Fatty acyl-CoA reductase and wax synthase from Euglena gracilis in the biosynthesis of medium-chain wax esters. Lipids. 2010;45:263-73.

21. Inui H, Miyatake K, Nakano Y, Kitaoka S. The physiological role of oxygen-sensitive pyruvate dehydrogenase in mitochondrial fatty acid synthesis in Euglena gracilis. Arch Biochem Biophys. 1985;237:423-9.

22. Inui H, Ono K, Miyatake K, Nakano Y, Kitaoka S. Purification and characterization of pyruvate: $\mathrm{NADP}^{+}$oxidoreductase in Euglena gracilis. J Biol Chem. 1987;262:9130-5.

23. Cramer M, Myers J. Growth and photosynthetic characteristics of Euglena gracilis. Arch Mikrobiol. 1952;17:384-402.

24. Tamoi M, Ishikawa T, Takeda T, Shigeoka S. Molecular characterization and resistance to hydrogen peroxide of two fructose-1,6-bisphosphatases from Synechococcus PCC 7942. Arch Biochem Biophys. 1996;334:27-36.

25. Arnon DI. Copper enzymes in isolated chloroplasts: polyphenoloxidase in Beta vulgaris. Plant Physiol. 1949;24:1-15.

26. Levasseur M, Thompson PA, Harrison PJ. Physiological acclimation of marine phytoplankton to different nitrogen sources. J Phycol. 1993;29:587-95.

\section{Submit your next manuscript to BioMed Central and take full advantage of:}

- Convenient online submission

- Thorough peer review

- No space constraints or color figure charges

- Immediate publication on acceptance

- Inclusion in PubMed, CAS, Scopus and Google Scholar

- Research which is freely available for redistribution 